\title{
Jottings From Greenwater
}

by Elizabeth Cruickshank, Regina

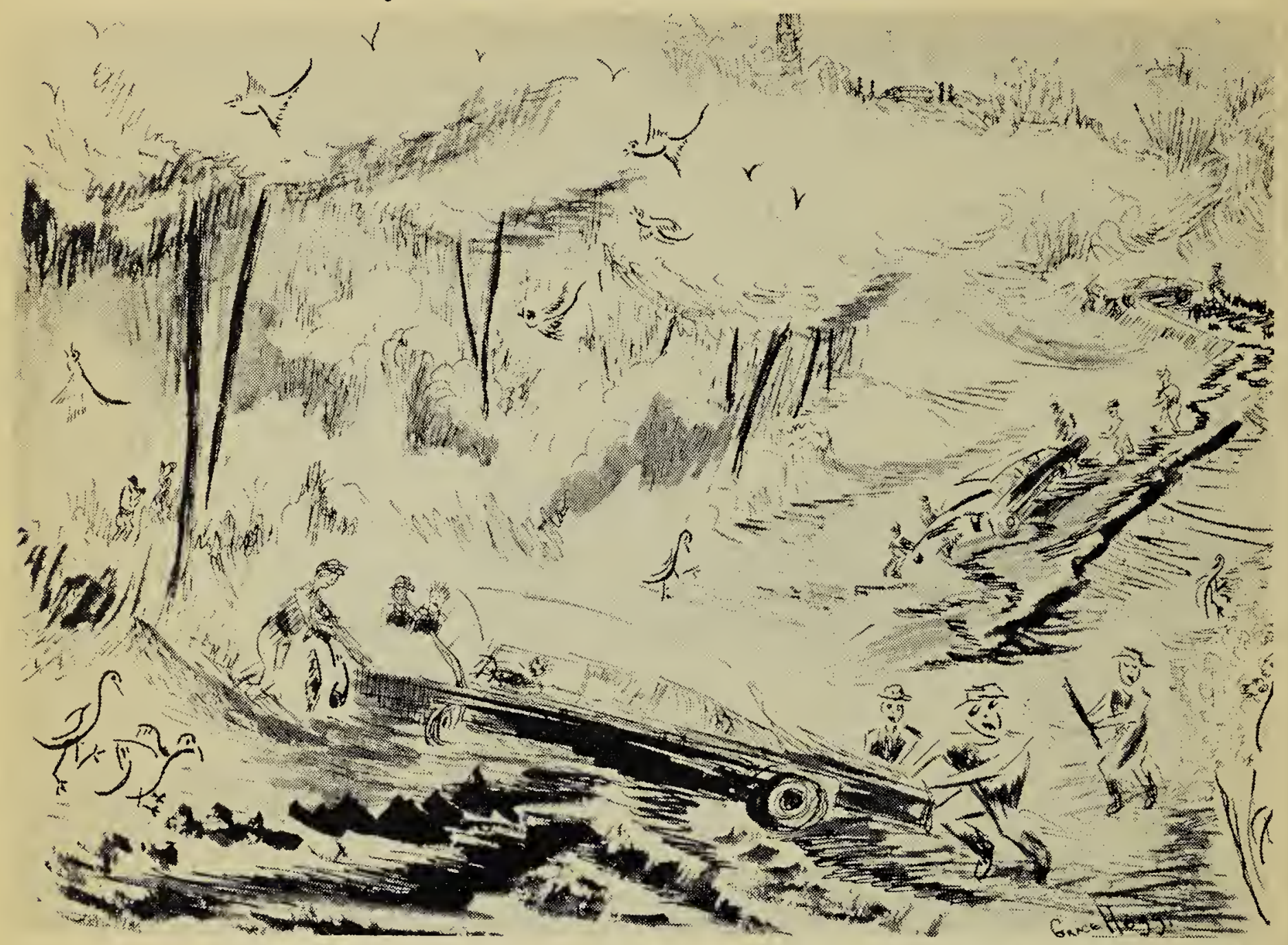

Birdwatching Greenwater Style!

Sketch by Grace Hogg

The sighting of a water tower seit on a high and distant hill proved to be an irresistible challenge to Stuart Houston. In spite of rain-soaked roads, half a dozen cars filled up at sunrise willing to follow the dedicated bird-bander. The blue station wagon, now a flying boat, reached the goal with its skipper. The mired, mud-weighted, shoving, slithering fellciw-travellers whose cars did ncit get through had the satisfaction of learning that a White-breasted Nuthatch and a Junco had been sighted by the intrepid crew. But this was only one episode in a pleasure-packed weekend at Greenwater Provincial Park when the Saskatchewan Natural History Society held its June meet there.

Jack Lane led the remnants of the tower safari to a wood full of Rosebreasted Grosbeaks. His uncanny aptitude for nest discovery and song recognition gave members also White-throats and Mourning Warblers. So keen was the delight as they watched and listened in the frogfilled bog, that black flies biting like demons went un-swatted!

Within the park Bill Brownlee, Lloyd Carmichael, Bernard de Vries, and George Ledingham acted as guides on hikes, pointing out exciting finds of orchids, ferns, grasses, Pileated Woodpeckers or Great Crested Flycatchers.

The evening of our arrival at the park was cool and wet and stacks of wood by the cabins were gratefully scanned. Frank Roy, however, found that the community axe was dull and useless! Lucy Murray gathered dry twigs but Frank Skinner, skilled in campcraft, demonstrated how to light a fire with whittled shavings. That proved a useful trick in the foggy dawn, and later helped us to dry soaked clothing. For the next meet we shall invest in a good pocket knife!

The following day the lake lay like a jewel of blue in the sunshine, and Loons and Red-necked Grebes could 
be seen swimming about. In this setting, swimming, boating and fishing were enjoyed to the full.

Michael Rhodes missed nothing in the form of birds, plants, feathers, footprints, frogs and pebbles! Other keen young members-John and Jane Ellis, Karen and Doug Shaw, and the Shadicks-noted everything around them with consuming interest.

The cavalcade to Little Nut Lake led by Anton and Steve Waycheshen gave thrills aplenty, including a Short-eared Owl's nest with seven eggs.

There were also nesits of grebes, Soras, loons, phoebes, Least Flycatchers. Most unexpected was one in the chimney of the cabin shared by Connie Pratt and Sylvia Harrison. Here a Golden-eye duck wanted to be counted among those present! While watching the Least Flycatcher's nest, Hummingbirds and Purple Finches flew past the open windows of the Lanes' car so often that the passengers expected momentarily that they would detour through the car.

Only flaw at the meeting was the lack of time for friends who meet only once a year to visit. There was no time to talk over experiences, trivial in themselves perhaps, but combining to make the meeting seem one of royal happenings and discoveries. These memories make a garland-lovely as the Greenwater orchids-to cherish with the new friendships made there.

To the Brownlee family, to the Park staff and management go grateful thanks.

\section{Notes from the Thelon Game Sanctuary, N.W.T.}

by E. Kuyt, Yellowknife, N.W.T.

I am stationed in Yellowknife with the Canadian Wildlife Service and have been in the field from June 16 until the present (June 24) in the Thelon River area collecting data on wolf biology. Here in the Thelon Game Sanctuary in the Keewatin District of the Northwest Territories the country is absolutely beautiful. Although mosit maps show the area to be north of the tree-line, it really isn't. There are a large number of white spruce here (some of a diameter of 1.2 inches at the butt, immensely old trees for their size I should imagine) favouring the sandy soil along the river and on the eskers, and dense thickets of several species of willow (some up to 8-10 feet tall) along the sandy shores of the river. Now that the waters of the river are receding, thickets of formerly submerged willows are becoming exposed forming a drab gray fringe along the river in some places and contrasting with the fresh green of the new willow growth higher up the bank.

We have been taking advantage of the high water by making frequent canoe trips-lack of daylight is certainly not one of our worries! The sun goes down around midnight and rises again in an hour or so. At all times there is enough light for taking photographs.

On one of our trips we were rewarded by the sight of three muskox bulls, quietly stripping the new leaves from the willows which appear to be their favourite food dur... ing the spring. They soon ran off, however, up over a rocky hillside, leaving a strong scent of musk among the willows where we examined the signs of their activities and looked at the bits of winter wool which the animals are shedding at this time. We marvelled at these impressive shaggy beasts as they nimbly clambered up the slope. The largest of them must have weighed close to a thousand pounds.

We also located the nesit with five eggs of an American Rough-legged Hawk on a steep cliff-side. There was a huge amount of nest material (dry sticks) at the bottom of the cliff and the nest itself was largeit had probably been in use several years.

The numbers and species of birds near camp are almost unbelievable. We have located 12 nests all within a few hundred yards of the camp merely by stumbling upon them- 